\title{
Hemingway: An Untragic Exile and Literary Genius
}

\author{
Mais Qutami
}

\begin{abstract}
Exile is a traumatic experience that is hard to overcome, but Earnest Hemingway chose voluntary exile as a style of living. Thrusting himself into foreign cultures and nations and detaching himself from everything familiar has stimulated him intellectually and enhanced his writing immensely. He was able to convey the truth about White America's relationship with "the other" through distancing himself from the homeland. His exilic status granted him "a plurality of vision" and multiple perspectives through which he saw the world and recreated it on the page turning him into a literary genius. This essay aims to highlight the positive impact exile had on Hemingway's writing.
\end{abstract}

Index Terms-Exile, Hemingway, literary production.

\section{INTRODUCTION: EXILE}

Edward Said defines exile as "the unhealable rift forced between a human being and a native place, between the self and its true home" [1]. Exile can be painful and unsettling for anyone who has left the homeland as Said asserts: exile is "terrible to experience" and "its sadness can never be surmounted." And although incidents of "heroic, romantic, glorious, even triumphant" moments in an exile's life exist in literature and history, they are merely efforts meant to overcome the crippling sorrow of estrangement [1]. Unfortunately, an exile never fully overcomes the impact of displacement and separation from the homeland, but makes attempts to build new loyalties and affiliations by becoming a citizen of the world since he/ she can no longer belong to the homeland that is lost.

The pain and sadness are true for the exiles who suffered humiliation and displacement due to war, colonization, or some form of oppression in their places of origin and exile was forced upon them. But many writers in the nineteenth and twentieth century such as Earnest Hemingway, among others, experienced a quite different type of exile that did not involve any uprootedness or dispossession due to war or the overtaking of their land. It was not the kind of exile where Third World people struggled for freedom or justice and were either forced out of their lands or just resorted to the First World in the hope of having a better life or gaining more human rights. In fact, Hemingway enjoyed the privilege of moving from one great advanced country to another in Europe and others outside of the First World any time he wished. He did not leave his country feeling a sense of loss or extreme bitterness about his departure as he was

Manuscript received March 1, 2015; revised July 7, 2015. This work was supported in part by Amman Arab University.

M. Qutami is with the English Language and Translation Studies Department, Amman Arab University, Jordan (e-mail: eternalmais@yahoo.com). well aware that he can return at any point. He also leaves knowing that he is an American citizen and his country would always be there should he decide to return and thus does not experience a great deal of nostalgia. The exile Said refers to, though, involves no return for the most part because the land has been ravaged and the individual has lost any hope to reclaim his land, but lives with many reminders of the lost homeland and shattered identity. Many exiles who were also intellectuals, due to these harsh circumstances, developed a need to engage in human rights issues and activism that promoted freedom and justice. They became activists who fought for the oppressed of all kinds and made their voices heard. That became the cause they dedicated their lives to, perhaps, due to the suffering of their families or ancestors who experienced actual exile and displacement. Hemingway, however, chooses to live in voluntary exile as a form of adventure away from his homeland and twentieth century America which he felt was racist and unwelcoming of "the other" whether it was Italian, Asian, African American, or Jew [2].

Exile, according to Michael Seidel, a UCLA professor and scholar, usually entails the destruction of the home place, rendering it "illegitimate, contaminated, or taken over by conquerors or rival claimants" and leaving those in exile in a state of trauma that "necessitate[s] their displacement" [3]. In Hemingway's case, his home place was not destroyed, or taken over by any conquerors and so no trauma had really necessitated his relocation or displacement. This kind of departure from the homeland that is not forced does not leave a permanent psychological scar in the individual like it would in the typical exile. Hemingway, the rather privileged exile, comes from the upper middle class whose family acted as a safety net while he was abroad. He also had an income from his part time position as writer for the Toronto Star and previously the KansasCity Star in addition to his first wife's inheritance he could fall back on should he need it. Hemingway was one of the upper middle class individuals who were labeled as "The Lost Generation" by Gertrude Stein whose most days were spent travelling, "wandering about the city writing, painting, sculpting, and socializing" [4].

Critics, actually, reveal that Hemingway was a rebel although he was brought up to be "a proper young Christian gentleman in the most suffocatingly proper suburb of Chicago" [5]. He left to Europe where he enjoyed great freedom from the "conformist and interfering nature of America which practices cultural hegemony" as cited in Domotor [6]. His letters convey an enthusiasm about the liberal presence of alcohol, lower cost of living in postwar Europe and other various "enchantments of foreign life" [7]. Hemingway's self- imposed exile was rather a form of privilege admired by many scholars and writers and is not viewed as a tragic event to be bewailed. On the contrary, 
exile became "sexy, glamorous, interesting" within postmodern thought as it involves, dislocation, uncertainty, displacement, and the fragmented identity, qualities people have come to value [8]. Exile, by the end of the nineteenth century, had even become "an attitude, a literary and intellectual way of observing the world" [9]. It became a style of life some writers chose when they feltdissatisfied with "the conditions of artistic or intellectual life in the homeland" [10].

Experiencing exile and a foreign setting can be eye opening as subtle discoveries can be made about oneself, other people, and the various trends in a given society. Being exposed to new landscapes and images can inspire and provide intellectual stimulation that may result in extraordinary writing as the writer adjusts to the new surroundings. Social interactions within the foreign culture can certainly be enlightening as well. Herlihy explains, "While the stimulation of foreign landscapes and activities heighten the fictional reproduction, so too do the extrasocial components inherent to national displacement" [4]. Hemingway is intrigued by the various cultures he experiences in Europe. Impressed with France, he begins to compare the foreign setting to America which he views as the inferior place: "What's the use of trying to live in such a goddam place as America when there is Paris and Switzerland and Italy. My gawd the fun a man has" as cited in Lynn [11]. After having spent several years away from the USA, his detachment from the homeland grows even further. In 1934, Hemingway makes his feelings about America known to the public as he states:

"I don't give a damn about America I can't help it ... it doesn't move me and it hasn't moved me for a long time and I can still be moved... I say the hell with it. I've seen better places and better people (Spain)" [12].

His experience in Europe helped him discover where he stands on many issues in America and later on develop a better understanding of his own homeland. His exile grants him a "plurality of vision" and a heightened sense of awareness of simultaneous dimensions. Said argues, "Most people are principally aware of one culture, one setting, one home; exiles are aware of at least two, and this plurality of vision gives riseto an awareness of simultaneous dimensions" [1]. Hemingway experiences multiple cultures simultaneously providing him with a unique insight into human nature and a broader view of the world in general that is transferred to his writing. He could not have developed this heightened sense of awareness and sensitivity toward everything happening were he to stay in his hometown.

\section{HEMINGWAY}

\section{A. Exile and Literary Production}

Hemingway's exile and another two factors referred to by Maddux and Galinski that improve artistic productivity are speaking another language, and "experiencing multiple cultures on a daily basis" [13]. This certainly applies to Hemingway who continuously crosses bridges between his own culture and others' and learns their languages and traditions. He states, "We who have lived in other countries as well as our own have spoken and understood the languages of these countries and have heard what was said by the people; we have something that cannot be taken from us" [14].

Hemingway cherished his experiences and interactions with other cultures which later became necessary for his literary career. There is evidence that cultural interactions in exile lead to creative output, whereas, those in the native land can inhibit an individual's ability to make certain connections due to familiarity. In other words, "exposure to and immersion within distinct linguistic, socio- cultural, and geographic contexts," as Hemingway did, "may result in a plurality of vision of sorts, which may facilitate the components of writing literature" [4]. Apparently, a writer's perspective and views shaped in the homeland are very likely to be different from those acquired in a foreign land that constantly forces him/ her into new situations and daily throws at him all kinds of challenges. The foreign setting, more often than not, leads to improved creative production and Hemingway realized this. Herlihy believes exile had a powerful impact on Hemingway's writing career: "It is the stimulation from the distinct places - geographic or socially constructed - that brought together the diverse circumstances he needed for writing literature. It was the man's displacement from Oak Park that initiated these interests" [4]. Hemingway's travels and participation in foreign social and cultural activities allowed him to explore his interest in bullfighting, fishing, shooting, and hunting which ultimately enriched his writing.

\section{B. Hemingway and America}

Hemingway finds it fascinating to be exposed to different cultures and locations. He incorporates what he sees and learns about foreign cultures into his writing, in addition to what he discovers about his own. One of his goals has been to provide a realistic portrayal of his homeland. He uses the stereotypical approach in representing the American social scene during that time [6]. He writes about non- American characters in many of his literary works not to demonstrate differences or similarities between nationalities, and neither is it to "reveal the superiority of the American stereotypical way of thinking." He exposes essential features he finds "lacking in American men" such as patriotism, the practice of tolerance, ability to sacrifice and develop "a greater breadth of view" [6].

In the story "Soldier's Home," Hemingway portrays a young American soldier as extremely frightened and totally changed by the war. Krebs is struck by society's indifference toward his return and attempt at sacrificing his whole life for the nation. He is even forced to weave stories from his imagination about war just to impress people and get them to listen to him. As he does this, he despises himself for resorting to lies and yet receives no compassion from people or any appreciation for being a patriot. Actually, he finds society hypocritical and demanding, as he is expected to overcome his traumatic experience at war and alienation at home, and return to his life prior to war. $\mathrm{He}$ realizes no one cares to know the truth about war or the scars it leaves behind, but still many urge the youth to fight "heroically." The narrator states: 
Krebs acquired the nausea in regard to experience that is the result of untruth or exaggeration, and when he occasionally met another ... soldier and they talked ... he fell into the easy pose of the old soldier among other soldiers: that he had been ... sickeningly frightened all the time. In this way he lost everything [15].

Through this story, Hemingway, shows what is "lacking in American men" such as courage and depicts American society as cold, unwilling to sacrifice, show compassion or tolerance, or even attempt to understand others' predicament. The irony in the title is demonstrated through Krebs' inability to feel at home in his own homeland and with his family leading us to the conclusion that a soldier, in fact, has no home once a soldier. While this story does not revolve around a foreign character, Hemingway deals with an American character who feels like a foreigner estranged in his own homeland. Such deficiencies in American society are what concern Hemingway in his writing and representation of America as he was disappointed in the whole century altogether.

In "A Very Short Story," Hemingway presents the relationship between an American man and an Italian nurse as boyish and immature love. They initially decide to get married and she would have to catch up with him after he gets a job in the USA. Later on, he receives a letter from her mentioning that what they had was just "a boy and girl affair" and that she would get married to the major of the battalion. Hemingway, in this story, utilizes a European female character who rejects an American male's love to represent the maturity of Europe compared to America the young and yet to mature nation. This is demonstrated through the disparate phases his protagonist and Luz live through. That is, they are not at the same point in their lives, while Luz is ready to open her own hospital and on her way to success, the American male is still embarking on a new endeavor where he will start a whole new life in America in the hope he would find a good job. The irony in the end is that Luz, the European women, never gets married to the major. This rejection of the American by the European figure reflects Hemingway's attitude toward his own nation. It is one of dissatisfaction with American identity, perceiving it as "never enough" especially in the eyes of the cultured European.

Hemingway's discontent with America also appears in his story "The Short Happy Life of Francis Macomber" through which he examines the development of a white American character in black Africa away from the homeland. The story does not celebrate the privileges White men enjoy, on the contrary, it focuses on the deficiencies a wealthy White American has in spite of all those advantages that help him get ahead in life. In the story, the white man is carried on the shoulders of Africans then turns out to be a coward unworthy of the respect he has received. Macomber and his wife have an unhappy marriage, but decide to remain in the relationship. Her beauty and his wealth do not seem to be enough to enjoy the life they have. The man's metamorphosis takes place in Africa where he steps out of his comfort zone and embraces this opportunity to search for the self he lost throughout the years. Macomber, the American, is a coward, emasculated by his wife, and only regains his lost masculinity in Africa. On his safari, and for the first time, he experiences a certain sensation of ecstasy and thrill over killing an innocent animal. Having shed his cowardice, he feels he has been reborn and finds himself excited about getting accustomed to this new person he has grown into. Finding the new identity is a great achievement for him that holds tremendous possibilities and potential. Unfortunately, right after this achievement, he dies, but with dignity and courage, in a land that is often portrayed as savage and lacking in pride and dignity.

The Africans in the story are represented as inferiors serving White tourists who come to rid themselves of the boredom and monotonous routine of their everyday life. For these individuals, savage hunting and murder of animals outside the sphere of high civilization function as cathartic moments and therapeutic outlets. It allows them to explore unusual sensations and formerly untapped aspects of their personalities. Ironically, only through savage killing does Macomber feel he is a strong and fulfilled soul which calls for a paradigm shift where notions of superiority, inferiority, and savagery set by White imperialists need to be redefined. Africa inspires and strengthens Macomber just as it has enriched Hemingway's writings through its mysteries and depth. In this way, Africa contributes to the development of his fictional characters, their maturity, and his intellectual growth as a writer. Through the events, readers come to appreciate Africa as well.

This story was inspired by Hemingway's real experience in Africa. As an exile, Hemingway lived in White Europe, more or less like the homeland, and wrote about it. Visiting Africa, however, a place considered "inferior" to his place of origin provides him with an entirely different mental and cultural experience and perspective. He enjoys the White man's privilege of visiting a darker race characterized as underdeveloped and barbarian by Eurocentric standards. There he feels the difference between nations, cultures, and the discrepancies between The First and The Third World, and still acknowledges the wealth and complexity of "the others" cultures within The Third World and the invaluable learning experience he has gained from them. His attitude can be sensed through his work as he was committed to sharing his revelations and knowledge of the world with his readers.

\section{Hemingway and "The Other"}

Hemingway once wrote that "A writer's job is to tell the truth" and he has always tried to represent life as it is in his writings. His whole work, in fact, was a "criticism of society" as cited in Walsh [16]. Hemingway, in exile, writes better about the USA as distance and relative detachment has provided him with a thorough understanding and a more sophisticated perspective of America. He has strived to represent the truth in his writings, and thus, his criticism of society is an attempt at reflecting on the ills of society and coming to terms with the emotions he has experienced about all the turmoil he has witnessed during American history. He lived through America's emergence as a global imperial power, the Spanish- American war, the two world wars, the revolution in Russia and Europe, the rise of fascism, and the Cold War [16]. He was a product of what he has experienced and witnessed, and his writings show his take 
on the highly charged political atmosphere and events that have touched his life.

Hemingway's writings uncover shameful acts driven by society's corrupt values in the 1920s. Some of these involve racial prejudice and discrimination against "the other," issues many avoid unlike Hemingway who reveals, through writing, his deep concern about different races in America, specifically, Native Americans and Africans. His concerns are very much justified as America in the twentieth century suffered from a sense of guilt toward Native Americans and tension with African Americans. These worries are not Hemingway's alone, but reflected an entire nation's feelings of insecurity about an altering racial typography [17].

Hemingway, enraged by what was happening at the time, refuses to sugar coat reality or his representation of "the other" in his short stories "Indian Camp" and "Ten Indians." In both stories, White superiority as it appears in association with the Indian "other" is quickly diminished as it is met by some type of failure that occurs and cannot be reversed. In "Indian Camp," for instance, the White doctor saves the Indian woman and delivers her baby but his success and role as savior is undermined by the death of her husband who the doctor was unable to save. Hemingway criticizes White society represented by the doctor in the story for not hearing the voices of the oppressed and considering "the other's" screams "not important." This incident reinforces Gayatri Spivak's claim in "Can the Subaltern Speak" that even if the subaltern speaks up, their voices will fall on deaf ears and will not be heard by Whites as they are perceived insignificant [18]. Nick asks, "Oh, Daddy, can't you give her something to make her stop screaming?" his father's reply is "No. I haven't any anaesthetic... But her screams are not important. I don't hear them because they are not important" [15]. In the story, the doctor receives praise from George who is impressed by his performance and operation on the Indian woman in labor and the doctor is also proud of himself. He states, "That's one for the medical journal, George ... Doing a Caesarian with a jack- knife and sewing it up with nine-foot, tapered gut leaders" [15]. This situation can be viewed from a postcolonial perspective through which the doctor represents the Orientalist and colonial power while the Indians become the Orient which is turned into an object suitable for study in the academy in this case, but in others can be used for display in a museum or reconstruction by the colonial machine or for theorizing about mankind and the universe in different fields of study such as linguistics, sociology, anthropology, psychology, and cultural studies [19].

The Indian woman becomes an object for study that intrigues Western scholars because the way the doctor approaches the case is rather unconventional and different from the mainstream. Ironically, her suffering is a subject that could make great research and further the white doctor's advancement within his medical career. This is a reminder of how the colonized can be useful to the West in its production of knowledge which in turn reinforces the superiority of the white race and already established dominance over the natives. The doctor, in the story, is there to save the patient, nevertheless, it is seen as an opportunity from which the white physician can benefit and use to his advantage as he contributes to the White man's medical scholarship which is viewed as "the" source of reliable knowledge above any other.

Hemingway is frustrated with US racism and discrimination as such, and addresses the issue extensively while he is abroad. He is unable to come to terms with the unsettling conditions in the USA especially when it comes to its racial minorities but is able to detach himself of it and write about it objectively. Hemingway's memoirs disclose that his "detachment - abstract and geographic - from the subject matter of fiction was a primary component of his creative practice" and he called this technique "transplanting" [4]. Apparently, Hemingway had often used transplantation to enhance his writing so he would write about one location while he resided in another, and thus distance was a literary resource he resorted to. For example, Hemingway wrote about Native Americans in his story "Ten Indians" during his stay in Madrid.

In "Ten Indians," Native Americans are represented as an inferior race through the derogatory terms used in describing them such as the continuous reference to them as "Them Indians" by Mrs. Garner. In the story, they are portrayed after one Fourth of July as drunk and smelly and one "face down in the sand" dragged into the bushes by Joe Garner. A dialogue takes place and Nick says he saw skunks and asserts he knows them when he sees them. Carl replies "You ought to ... You got an Indian girl ... [and] they smell about the same" [15]. The dialogue reflects the way some Whites perceive Indians and associate them to animals, as Carl thinks the Indian girl's smell resembles the skunk's, while Nick falls in love with one of them and is happy to be teased about the young Indian girl. It is rather significant that a Native American is depicted as drunk with his "face down in the sand," devoid of human dignity and respect, particularly on the Fourth of July. Sadly, this date holds painful memories for the Indians who were defeated, lost their land, and were displaced forever. On the other hand, the very same date holds an entirely different meaning to Whites. It celebrates the adoption of the Declaration of Independence and the birth of America as an independent nation. Nevertheless, celebrations of American victory are deflated by Nick's failure to keep his Indian girl as he loses her to another boy on the Fourth of July. Nick gets his heart broken that night for the first time. "He had been crying ... Nick lay in the bed with his face in the pillow." This line alerts the reader to its connection to the situation depicted of the Indian with his "face down in the sand;" Hemingway, deliberately, draws such a connection to interrogate the "us" and "them" dichotomy and correct any misconceptions about the gains of occupation and colonization.

The implied failure of American characters in Hemingway's stories are not necessarily an attack on the USA, but rather a reflection of the degree to which Hemingway is true to himself and committed to representing life as it is with an objective eye. He is indifferent to imperialists' wish and efforts to present a distorted reality to the public or their fabricated images of success, democracy, and freedom that only serve their own agenda. The two stories about Native Americans reinforce the notion that forgiveness and reconciliation with White supremacist is an option with limited possibilities due to the severity of the natives' suffering. Hemingway's stories 
about Native Americans were inspired by his numerous and exciting interactions with Native Americans from his childhood. The Hemingway children and Earnest were familiar with their cultural traditions as they frequently visited Indian Camp in Michigan where the young Earnest was often dressed, by his mother, in a Native American outfit or straw hat and overalls [20]. He and his father, a physician, used to accompany one Native American for rifle shooting practice and had formed a friendship with him as Dr. Hemingway treated many in the Indian Camp for free [20]. These childhood memories had an impact on his writing and representation of Native Americans. His stories demonstrate sympathy toward their predicament and his identification with them.

Studies show that Hemingway was fascinated by the primitive and identified with primitive people and cultures. Not only did he observe them or study them, but sometimes sought to become one of them "through some rite of initiation or feat of analogy" [21]. He, actually, identified with people from different racial backgrounds whether they were non- white or racially similar to him like the Spanish, French, or British as seen in his writings [22]. Hemingway's stance on political and social issues usually appears through his depiction of characters and their cultures such as Krebs, Luz, Macomber, Nick, and the Indian girl. And through the selected short stories examined in this essay, he was able to recreate life that speaks volumes of what real life looks like and how Whites think, act, and perceive "the other" of different races.

\section{CONCLUSION}

Hemingway was a Nobel Prize winner and an important figure in American culture and history. He produced exceptional writings although he never went to college. He read extensively and strived to write with creativity and authenticity revealing what he has experienced in his journey of self- discovery and exploration of other cultures and nations. His exile, and visits to France, Spain, Cuba, and Africa, was a milestone in his literary career and a tool for inspiration. He himself inspired and influenced many writers in the $20^{\text {th }}$ century and beyond including Raymond Chandler, Ralph Ellison, Richard Yates, Raymond Carver, James Cain, Jean- Paul Sartre and others [16]. Hemingway’s achievements as a literary writer prove that the exilic status he chose for himself was certainly rewarding and not without challenge.

\section{REFERENCES}

[1] E. Said, Reflections on Exile and Other Essays, Cambridge: Harvard University Press, 2002.

[2] J. A. Schwarz, "Who's the foreigner now? Rethinking 1920s American prejudice in A Farewell to Arms," in Hemingway's Italy:
New Perspectives, R. Sanderson, Ed. Louisiana: Louisiana State University Press, 2006, pp. 108-116.

[3] M. Seidel, Exile and The Narrative Imagination, New Haven and London: Yale University Press, 1986.

[4] J. Herlihy, In Paris or Paname: Hemingway's Expatriate Nationalism, Amsterdam- New York: Rodophi, 2011.

[5] A. Kazin, "Hemingway the painter," The New Republic, vol. 176, no. 12, pp. 21-28, March 19, 1977.

[6] T. Domotor, "Hemingway's In Our Time: Masks, silences and heroes," Ph.D. dissertation, Dept. English, University of Surrey, Guildford, Surrey, United Kingdom, 2012.

[7] J. Herlihy-Mera, "When Hemingway hated Paris: Divorce proceedings, contemplations of suicide, and the deleted chapters of The Sun Also Rises," Studies in the Novel, vol. 44, pp. 49- 62, 2012.

[8] E. Hoffmann, "The new nomads," in Letters of Transit: Reflections on Exile, Identity, Language, and Loss, A. Aciman, Ed. New York: New Press, 1999, pp. 35-65.

[9] I. Buruma, "The romance of exile- real wounds, unreal wounds," The New Republic, Feb. 12, 2001, pp. 33-38.

[10] J. Cawelti, "Eliot, Joyce, and exile," ANQ: A Quarterly Journal of Short Articles, Notes and Reviews, vol. 14, pp. 38-45, 2001.

[11] K. S. Lynn, Hemingway, New York: Simon and Schuster, 1987.

[12] E. Hemingway, Selected Letters 1917-1961, New York: Scribner, 1981.

[13] W. Maddux and A. D. Galinsky, "Cultural borders and mental barriers: The relationship between living abroad and creativity," Journal of Personality and Social Psychology, vol. 96, pp. 1047-1061, 2009.

[14] E. Hemingway, Complete Poems, Lincoln: NB, 1992.

[15] E. Hemingway, The First Forty-Nine Stories, London: Jonathan Cape, 1944.

[16] D. Walsh, "Fifty years since the death of Ernest Hemingway," World Socialist Website, July 6, 2011.

[17] M.K. Dudley, Hemingway, Race, and Art: Bloodlines and The Color Line, OH: Kent State University Press, 2011.

[18] G. Spivak, "Can the subaltern speak?" in Marxism and the Interpretation of Culture, C. Nelson and L. Grossberg, Eds. London: Macmillan, 1988, pp. 271-313.

[19] E. Said, Orientalism, New York: Pantheon Books, 1978.

[20] J. Cohassey, "Hemingway's 'Last Good Country'," Metrotimes, July 7, 2010.

[21] S. Del Gizzo, "Going home: Hemingway, primitivism, and identity," Modern Fiction Studies, vol. 49, pp. 496-523, 2003.

[22] A. Strong, Race and Identity in Hemingway's Fiction, New York: Palgrave Macmillan, 2008.

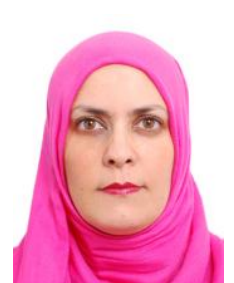

Mais Qutami received her Ph.D in $20^{\text {th }}$ century American and multiethnic literature from Indiana University of Pennsylvania, USA, 2009.

She has worked as an assistant professor of English in the English Language and Translation Studies Department, Amman Arab University, Jordan, and the University of Nizwa, a teaching associate at the Literature and Criticism Department, Indiana University of Pennsylvania, USA, and a lecturer of English at The University of Jordan and ALBalqaa Applied University, Jordan. She has published "Exiles turn lemons into lemonade: Multiethnic poets of the US crossing borders," Journal of Literature and Arts Studies, vol. 11, pp. 951-964, 2014. "The veil (de)contextualized and nations "democratized": Unsettling war, visibilities, and U.S. hegemony," in Works \& Days. Invisible Battlegrounds: Feminist Resistance in the Global Age of War and Imperialism. S. Comfort \& D. Downing, Eds. IUP, vol. 29, pp. 159-178, 2011. Her research interests include postcolonial theory and literature, Arab Islamic Feminism, multi-ethnic and comparative literature.

Dr. Qutami received the Outstanding Graduate Student Research Award for her dissertation. 